\title{
2 Institutional EnTREPRENEURS AS Change Agents in Rural-Peripheral Regions?
}

\author{
Birgit LEICK, University of Southeastern Norway, Institute of Business \\ and IT, Norway
}

\section{Content}

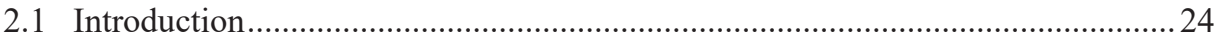

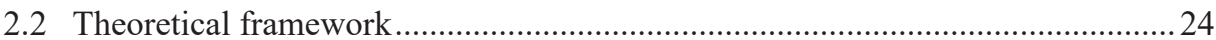

2.2.1 The essence of entrepreneurship and innovation for regional

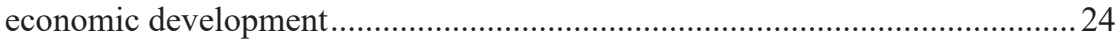

2.2.2 Coming across institutional entrepreneurship in rural-peripheral regions: Innovative entrepreneurs residing outside companies.........................26

2.2.3 What is institutional entrepreneurship? A snapshot of the literature .................27

2.3 Discussion: Institutional entrepreneurs as change agents in rural-

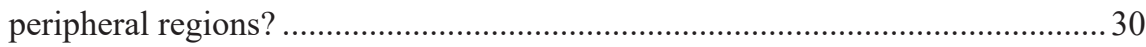

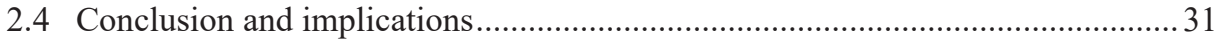

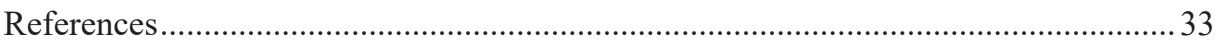

The present paper emphasises a different perspective on entrepreneurship for regional contexts that goes to the core of the question of who and what an entrepreneur can be and how entrepreneurs contribute to regional economic development. The answer that this paper offers focuses on institutional entrepreneurship, which encompasses the idea that there is a wider field of agents in regions than owner-managers of companies. It is argued that manifold actors can show entrepreneurial behaviour and bring about a disruptive transformation of the regional economy. With new combinations of resources, knowledge and ideas, but also with their capabilities to strategize, mobilise and lead collective action, institutional entrepreneurs represent such change agents that can support economic development notably in rural-peripheral regions. 


\subsection{Introduction}

This short article is based on the idea that entrepreneurial activity can be found outside enterprises and that such non-corporate entrepreneurship may contribute to regional economic development processes. More specifically, the paper aims to highlight notably the capacities of so-called institutional entrepreneurs to support change in institutionalized behaviour for the sake of fostering economic development. The idea of institutional entrepreneurship is not new, but the concept has remained for a long time inside the area of organizational studies. Only in recent years have researchers in regional studies taken it up and applied it to regional economic development questions.

In line with this emergence of a new perspective on entrepreneurship, the paper aims to give a conceptual framework for understanding institutional entrepreneurship for economic development of notably rural-peripheral regions. Its message is that various actors in rural-peripheral regions - including enterprises and persons aligned to enterprises - may represent institutional entrepreneurs and important agents of change that can support regional economic development processes.

The paper will be organized as follows. The next section will briefly review the mainstream understanding of entrepreneurship, innovation and regional economic development. It will be followed by anecdotal experience with non-corporate entrepreneurs in a rural-peripheral region, thereby raising some important questions about who can be an entrepreneur and whether individuals from public administration may be considered as entrepreneurs. The following sections are devoted to review institutional entrepreneurship as a concept and apply it to regional economic questions. The paper closes by stressing both limitations and caveats and avenues for future research along this line.

\subsection{Theoretical framework}

\subsubsection{The essence of entrepreneurship and innovation for regional economic development}

The question of what an entrepreneur is dates to the famous economist Joseph SCHUMPETER, who coined the idea of the creative destruction that entrepreneurs with their new resource combinations bring about (SCHUMPETER 1934). Subsequently, this original idea was refined in economics with the notions of the "innovating entrepreneur" (BAUMOL 1993) as well as the "firm-organizing entrepreneur" (GARTNER et al. 2010), i.e., enterprising individuals embedded in a firm organization, who perform innovation within this boundary. These ideas from the past and recent history of economic thought 
on entrepreneurship highlight two important elements in the mainstream understanding of entrepreneurship: first, the entrepreneurial and innovative element in both perspectives is the disruption of existing production processes, and even markets, leading to innovation; and, second, the fact that the innovative solution created by the entrepreneurs is commonly organized by enterprising individuals or companies embodying such individuals.

If we take these ideas to the question of how entrepreneurship can contribute to regional economic development or growth, most underlying theories actually focus on corporate entrepreneurship, which embodies the idea of the "firm-organizing entrepreneur" (GARTNER et al. 2010), as a vehicle to transform new ideas and creativity into marketable products and services, and, hence, innovate on markets. In fact, entrepreneurship is commonly understood as a process starting with a new market opportunity by an enterprising venture, which leads to the formal set-up and registration of a new company with the goal to operate in a market for the sake of generating profits and supplying goods or services to that market (cf. Shane \& VenkatARAMAn 2000). BruYAT and JuliEN (2001, p. 168) describe some basic tenets in entrepreneurship research as follows: Entrepreneurs create value for the economic process, learn and are creative in doing so, and they are shaped by the environment in which they are embedded. Hence, the entrepreneur faces competition in the market with a new product or service and needs to compete against other suppliers (unless it is a monopolistic market) to fill the needs of the customers buying the product or service. After a more or less short start-up period comes the litmus test that will prove of whether the entrepreneur and the new company survives in the competitive market with the innovative product or service (cf. WENNEKERS \& THURIK 1999). As a matter of fact, corporate entrepreneurship is closely connected to the location where it takes place (cf. MALECKI 1993), but this connection has, of course, become more loose in the global and increasingly digital world.

Notably in rural-peripheral locations, where there is commonly a lower density of companies as well as low prevalence of large, innovating corporations (EDER 2019; DolOreux \& DiOnNe 2008; cf. TunBerg 2014; NALDI et al. 2015), entrepreneurs - both new start-up ventures and incumbent companies - need to build and diversify their business model in creative and dynamic ways in order to sustain their competitiveness for their company growth, but also to create jobs and invest locally. Given a location outside major urban centres, corporate entrepreneurs might, however, benefit from tradition and entrepreneurial networks supporting their company growth and sustainability in the location (cf. BENNEWORTH 2004). Entrepreneurs thereby turn into important carriers of regional economic growth and development processes.

By the afore-mentioned description of an entrepreneur, social entrepreneurs will be explicitly included, who aim at starting innovative ventures and take risks in order to reach social value (Peredo \& McLean 2006), but not necessarily to maximise their own returns. In a context of rural-peripheral regions, examples are the so-called "Dorfzentren" or "Dorfläden" (rural corner stores), a concept that is driven by enterprising 
individuals with strong welfare goals for the small-scale rural community as well as the wish to create social value for local consumers and dwellers. Social entrepreneurship with individual risk-taking and venturing despite altruistic goals is also connected to the creation of social innovation (CAJAIBA-SANTANA 2014).

In a more general way, such entrepreneurs can drive innovation processes and, through the generation of innovation, positively influence the economic growth (Acs 2006) and development potential of a region. MuelLer (2007) shows that a higher number of innovative entrepreneurs are associated with regional economic growth. Hence, entrepreneurs are a driver of innovation, including social innovation, which may benefit regional economic development by means of their mass. For rural-peripheral regions, the lack of critical mass of entrepreneurship represents an important challenge for regional growth.

\subsubsection{Coming across institutional entrepreneurship in rural- peripheral regions: Innovative entrepreneurs residing outside companies}

To start with an anecdote: In 2013, I was working for head of a local business development agency that was integrated in a municipal administration in a peripheral region in Germany. With about 40,000 inhabitants, the city had experienced a steady downturn in a process of structural change with steady industry layoffs and a subsequent outmigration of notably young people in the past decades. Yet, the city hosts several successful small- and medium-sized companies, which were competing on global markets, while other companies in the city were struggling hard to survive.

The retail trade was a local sector that was fighting to survive because of the outmigration and ageing of the city. One retail trader tried to experiment with new approaches to sales and marketing, an online trade shop, and attempts to reach out to new target groups inside the city and beyond. However, he felt too small to really combat the rising online trade and changing shopping patterns of notably the young generation. Since many of his regular customers died over time, he could not replace them to a sufficiently high degree with young customers, leading to decreasing sales and losses over time. This was the example of an entrepreneur, who was thinking in innovative categories, trying out new product variant, new sales and marketing channels, etc., yet he was failing on the shrinking and challenging local market.

When I was talking about this case with the head of the business development agency, he presented me with a different view on the retail trader, saying that, if he were the entrepreneur, he would try out completely different strategies. He listed several strategies that not only sounded more radically innovative - in the sense of being new and not-yet-predicted - but also more feasible and appropriate to the local challenges that a small entrepreneur meets in such an environment. Two things became evident for 
me: First, this administrative leader demonstrated a more pronounced entrepreneurial thinking and more radical innovativeness in his approach than the actual entrepreneur, that is, owner-manager of the retail company. Second, the immanent creativity that the administrative leader presented in his approach regarding local problem-solving brought to the fore more radically disruptive ideas about changes in the entrepreneur's ailing business model than the retail trader could realise himself.

Three evident questions attached to this case are as follows:

1. Can this public employee be considered as an entrepreneur, although he does not match the mainstream criteria of the corporate (firm-organizing and innovating) entrepreneur?

2. In case that this represents entrepreneurship, what kind of entrepreneurship can such a non-corporate actor represent?

3. How can such entrepreneurship then benefit regional economic development, notably with regard to rural-peripheral regions?

My main argument in the present paper and - at least partial - answer to the three questions will be that actors outside companies who develop such radically innovative ideas and take action towards changing the institutional settings in their regions in a way that the new ideas may be adopted by others are associated with institutional entrepreneurship. Institutional entrepreneurs are thus conceptualised as actors whose goals and actions are targeted at changing the institutionalised behaviour of the regional companies, thereby promoting institutional change driven by agency (cf. LeICK \& GRETZINGER 2018).

\subsubsection{What is institutional entrepreneurship? A snapshot of the literature}

Regarding the first question posed - What kind of entrepreneurship the behaviour of the public policy agent represents if it is not related to corporate entrepreneurship? -, it can be acknowledged across various research strands (e.g., BATTILANA \& CASCIARO 2012; HENREKSON \& SANANDAJI 2010; Li et al. 2006) that institutional entrepreneurs are commonly seen as agents who work to change institutionalised patterns of thinking and acting. Hence, the concept incorporates elements associated with elements taken from both entrepreneurship theories and institutional accounts (cf. LEICK 2017).

Institutions are generally viewed as being based on culture, tradition, values and norms, but also on legal frameworks, which, with informal and formal guidelines, guide 
the patterns of thinking and acting (cf. Hardy \& Maguire 2008; North 1990). It is furthermore assumed that institutions change over long cycles only and, thus, persist over time, growing more fixed into a long-lasting framework which guides the decisionmaking processes of economic actors (cf. RAFIQU 2009). In other words, institutions are subject to change mainly through long-term interaction processes within the economy and society (cf. NORTH 1990).

However, in times of transformation and, perhaps, crisis in the mainstream production modes such as the contemporary spatial transformation in the age of globalisation and digitization, the persistence of institutions might create operational conflicts for economic actors. Existing laws, rules and norms might no longer fit the latest developments in business, economy and society; the commonly employed patterns of behaviour of economic actors might not lead them to take appropriate strategies to cope with emerging challenges and impair their firm-level competitiveness as well as regional economic growth, for instance, regarding the employment and investment outlook of companies. In such contexts, agents stemming from both inside the circle of corporate entrepreneurs and outside might enter the plan to set up and promote new strategies and patterns of behaviour (cf. LEICK 2017).

This way of thinking, indeed, reflects a more recent understanding in entrepreneurship, which does not only view institutions as factors influencing and limiting entrepreneurial activity (e.g., APARICIO et al. 2016), but that acknowledges that economic actors such as entrepreneurs and others may change the institutional frameworks surrounding them (cf. HenReKSON \& SANANDAJI 2010).

Institutional entrepreneurs as such agents that challenge existing institutions are defined according to SotaRAUTA \& PULKKINEN (2011, S. 100) as "individuals, organizations, or groups of actors who not only introduce the needed change and/or innovation but also work to change the broader context so that the innovation has a widespread appeal and impact". The concept of institutional entrepreneurship has its roots in organizational theory, that is, sociological accounts, and mainly describes individuals from the core or the periphery of business organizations who trigger or push change processes within the organization (cf. Hardy \& Maguire 2008; Battilana et al. 2009). These individuals are not necessarily the ones in upper echelons but can be outsiders who organize support for their change plans within the organization.

Furthermore, PERKMANn (2002, p. 124) clarifies that "institutional entrepreneurs are not necessarily individuals. They can be organizations or even (policy) networks". In the context of regional economic development, agents that might turn into institutional entrepreneurs thus comprise a broader group of actors that might support regional change processes, for example, organized non-governmental and civic actors ${ }^{1}$, regional and municipality-level policy-makers, and grassroot movements among citizens as well

A recent example is the group of 'Fridays for Future' youth with their change plans for environmental policies in several European countries. 
as individual citizens ${ }^{2}$. These actors (and in the groups, the key persons among them) can either hold key positions for regional development policy or practice, or they can also be actors coming from outside the key positions (cf. HARDY \& MAGUIRE 2008).

Altogether, institutional entrepreneurship in a regional context is about actors with the capacities of entrepreneurial thinking and innovative concepts that target change in the existing production and organization processes in the region. Because of these characteristics, they represent potential mentors of the change and agents that support the change to come (cf. KALANTARIDIS \& FLETCHER 2012). Hence, the concept of institutional entrepreneurship differs from the idea that agents within regional economies may innovate within the larger framework of the existing institutions in a region (GRILLITSCH 2019) because the idea behind the concept of institutional entrepreneurship is more radical in this matter.

Regarding the second question - What kind of entrepreneurship institutional entrepreneurs represent and under which conditions institutional entrepreneurship may unfold? -, three essential characteristics or behavioural traits are highlighted in the literature (Sotarauta \& PUlKkinen 2011; Sotarauta 2009; cf. Leick 2017):

1. Institutional entrepreneurs display strategic thinking coupled with foresight (albeit not necessarily goal-oriented, according to Sotarauta \& PUlKkinen 2011, p. 101), which makes them able to be future-oriented in their perspective.

2. Institutional entrepreneurs have or strive to obtain power based on networks or alliances and dominate interpretative patterns created through their power of networking (SOTARAUTA 2009).

3. Institutional entrepreneurs have leadership competencies and political skills (SotARAUTA \& PULKKINEN 2011: 102-103), which makes them mobilise alliances, networks and movements as well as pooling knowledge and competencies.

These characteristics originate from two different theories within the wider field of institutional theories in social sciences (cf. PACHECO et al. 2010). As a common denominator, it is proposed that institutional entrepreneurs may have a self-interest (like the corporate entrepreneur), yet sometimes a more altruistic motivation (in line with the understanding of social entrepreneurship). Moreover, their capacities to mobilise groups in order to set in motion a 'political' process of changing informal, institutionalized behaviour or formal institutions are seen as a key to explaining the power of turning into agents of change (PACHECO et al. 2010). This is due to leadership skills to build networks and alliances that institutional entrepreneurs possess (cf. HARMAAKORPI \& NIUKKANEN 2007).

2 Local citizenship initiatives for specific local or regional concerns that develop into local parties in the municipality/city council or even regional parliaments are good examples of former grassroot movements. 
According to the main theoretical foundations of institutional entrepreneurship, these three leading characteristics determine the approach to institutional change by institutional entrepreneurs because agents showing these characteristics may turn into "agents of change".

\subsection{Discussion: Institutional entrepreneurs as change agents in rural-peripheral regions?}

By answering the two afore-mentioned questions, a third question can be addressed: Why can institutional entrepreneurs represent key agents of change to promote regional economic development? The present section aims to give some answers to this third question.

From the theory, it becomes evident that institutional entrepreneurs bring new approaches to thinking and problem-solving to existing communities of economic and non-economic actors in regions. They do not directly or indirectly influence economic growth and value-creation through innovation processes, as both corporate and social entrepreneurs are supposed to do (cf. MALECKI 1993; WenNeKERS \& ThURIK 1999; AUdRETSCH \& KEILBACH 2004). Instead, institutional entrepreneurs have the capabilities needed and seize opportunities they identify to promote change given their endowment with the necessary resources such as contacts, networks, and financial resources (cf. LeICK 2017). Proactiveness and commitment according to strategic outset, in combination with entrepreneurial thinking, are other important capabilities that such potential change agents are vested with in order to promote economic development of ruralperipheral regions. Finally, competencies to lead political negotiation processes with the groups which institutional entrepreneurs mobilise are necessary to make an impact on and unite like-minded supporters (SotaRAUta 2009; cf. LeIcK 2017). Therefore, such actors can but do not automatically enforce and promote change in the institutions (BATTILANA et al. 2009).

The empirical evidence on institutional entrepreneurs, their activities in regional contexts and their potential impact on regions is scarce. Generally, change in industries and markets is seen as one trigger of the entrepreneurial, change-seeking activities by institutional entrepreneurs (Battilana \& Casciaro 2012). Perkmann \& Spicer (2007) as well as PERKMANN (2002) describe such agents in the process of administrative regionbuilding for cross-border regions. SotARAUTA \& PULKKINEN (2011) show the influence of institutional entrepreneurs on regional innovation systems. SOTARAUTA (2010) calls them "bricoleurs" of institutional change because this change typically results from a bottom-up process (cf., also, Horlings \& PADT 2013). MAHzouni (2019), by contrast, highlights the more organized, group-based form of institutional entrepreneurship in the process of a municipality-level transfer to renewable energies. Finally, LEICK \& 
GRETZINGER (2018) show the case of researchers who have been pushing change in a local city administration based on their applied research project work.

Hence, there seems to exist a variety of potential change agents in regions that can be associated with institutional entrepreneurship, depending on the field of activity, degree of organization, and other factors. This diversity in the change-seeking agents is important for rural-peripheral regions because these regions typically host only a few large corporations with managers who can and are willing to take over such a leadership role and the small- and medium-sized enterprises prevailing in rural-peripheral regions might lack the resources to step in the role (cf. EDER 2019, DOLOREUX \& DiONNE 2008). Moreover, rural-peripheral regions typically lack a critical mass of such agents (cf. MENG 2013). Still, individual managers and owner-managers of companies including the companies as such may be change-makers themselves (cf. GiLLy et al. 2014), which would be the case that corporate entrepreneurs would represent institutional entrepreneurs simultaneously.

Change agents outside companies may therefore complement the regional corporate entrepreneurs to support and promote change that benefits regional economic development goals. Here, the interpretation of the concept 'institutional entrepreneurship' is overlapping with related approaches, e.g., policy entrepreneurship as individual change agents (Frisch-Aviram et al. 2018; WiLLi et al 2018) and the more general idea of GRILLITSCH (2019) about path-breaking innovative entrepreneurs.

However, it is important to add that there is no automatism in that actors outside enterprises such as politicians and administrative managers may be institutional entrepreneurs. This caveat is put forward by SotaRAuta \& PULKKInen (2011, p. 98) as follows: "(i)t would be tempting to assume that mayors, leading policy makers, and other acknowledged authorities would somehow automatically be institutional entrepreneurs. This is often a false assumption". HugGins (2000), for example, rather shows that policy-led initiatives may be prone to failure, which makes it necessary to look critically at the capacities of actors from the policy and public administration arena when it comes to determining who is a potential institutional entrepreneur.

\subsection{Conclusion and implications}

With this depiction, I am far from drafting an idealised picture of institutional entrepreneurs as change agents in rural-peripheral regions. My goal is therefore not to convey the impression that the concept might be a prescriptive model which policymakers should develop and use for regional economic development plans and strategies. My message is a rather opposite one, that is, that institutional entrepreneurs such as other, corporate and social entrepreneurs, might represent important channels where regional change agency may originate from. In other words, institutional entrepreneurs 
may form part of a larger variety of bottom-up channels of agency working in regional economic development, implicitly or indirectly such as entrepreneurs do, or explicitly and directly as, for instance, policymakers and public administration leaders do. Altogether there is a broader range of potential institutional entrepreneurs with regional companies, citizens, and policymakers and administrative leaders, but it is by no means an automatism that institutional entrepreneurship will automatically unfold with the help of policy programmes and action plans.

Against the backdrop of this caveat, the message that this paper wishes to convey is that such agents of change might primarily be seen as complementary routes to institutional change in regions besides the existing top-down programmes. The key asset with institutional entrepreneurs for regional economic development is maybe that such individual or collective commitment to change institutions could amend both policy programmes and market-driven approaches by entrepreneurs and companies in notably rural-peripheral regions. Because institutional entrepreneurs have capabilities to strategize, mobilise collective action and lead the action, they might instigate change in a more radical and path-breaking way because they identify voids and conflicts in institutions as well as needs from the companies and citizens.

However, it is important to note that an important driver for institutional entrepreneurs to enter the plan and work for change is their self-interest in a specific institutional set-up. In other words, proactive commitment by such agents might not per se result in shared goals and altruistic values. Hence, the idea of this article is also to underline potential challenges when using institutional entrepreneurship as a concept for regional planning practice.

Another challenge is related to the lack of evidence how the concept fits agents of change in regions. Given that most of the available empirical evidence on institutional entrepreneurship stems from organizational sociology and is located within organizational theory, strategic management and general business administration, there is a knowledge gap on the role of such agents notably in the context of regional economic development. The scarcity of literature makes further empirical studies necessary that can contribute to theory-building for regional studies and amend the existing literature on regional innovation systems and leadership in business networks/clusters.

Only after this cross-fertilization of concepts will have taken place, the concept of institutional entrepreneurship might be used as a lens to develop policy tools. Still, there is a lot to learn for regional policy, and the general take-home message of the present paper is that individual and collective actions, shown by bottom-up processes in regions, should be internalised in existing policy-making in order to transfer the best ideas and solutions for regional challenges to all involved stakeholders in a regional economy. 


\section{References}

Acs Z. (2006), How is Entrepreneurship Good for Economic Growth? Innovations 1(1), pp. 97107.

Aparicio S., Urbano D., Audretsch D.B. (2016), Institutional Factors, Opportunity Entrepreneurship and Economic Growth: Panel data evidence. Technological Forecasting and Social Change 102, pp. 45-61.

Audretsch D.B., KeILBACh M. (2004), Entrepreneurship and Regional Growth: An Evolutionary Interpretation. Journal of Evolutionary Economics 14(5), pp. 605-616.

Battilana J., Leca B., Boxenbaum E. (2009), How Actors Change Institutions: Towards a Theory of Institutional Entrepreneurship. Academy of Management Annals 3(1), pp. 65-107.

Battilana J., Casciaro T. (2012), Change Agents, Networks, and Institutions: A Contingency Theory and Organizational Change. Academy of Management Journal 55(2), pp. 381-398.

Baumol W.J. (1993), Formal Entrepreneurship Theory in Economics: Existence and Bounds. Journal of Business Venturing 8(3), pp. 197-210.

Benneworth P. (2004), In What Sense 'Regional Development?': Entrepreneurship, Underdevelopment and Strong Tradition in the Periphery. Entrepreneurship \& Regional Development 16(6), pp. 439-458.

Bruyat C., Julien P.A. (2000), Defining the Field of Research in Entrepreneurship. Journal of Business Venturing 16(2), pp. 165-180.

Cajaiba-Santana G. (2014), Social Innovation: Moving the Field Forward. A Conceptual Framework. Technological Forecasting \& Social Change 82, pp. 42-51.

Doloreux D., Dionne S. (2008), Is regional innovation system development possible in peripheral regions? Some evidence from the case of La Pocatière, Canada. Entrepreneurship \& Regional Development 20(3), pp. 259-283.

EDER J. (2019), Innovation in the Periphery: A Critical Survey and Research Agenda. International Regional Science Review 42(2), pp. 119-146.

Frisch-Aviram N., Cohen N., BeERi I. (2018), Low-level bureaucrats, local government regimes and policy entrepreneurship. Policy Science 51(1), pp. 39-57.

Gartner W.B., Carter N.M., Reynolds P.D. (2010), Entrepreneurial Behavior: Firm Organizing Processes. In: Acs Z., Audretsch D. (eds.), Handbook of Entrepreneurship Research. Springer, New York, pp. 99-127.

Gilly J.P., Kechidi M., Talbot D. (2014), Resilience of Organisations and Territories: The Role of Pivot Firms. European Management Journal 32(4), pp. 596-602.

GriLlitsch M. (2019), Following or Breaking Regional Development Paths: On the Role and Capability of the Innovative Entrepreneur. Regional Studies 53(5), pp. 681-691.

HARMAAKORPI V., NiUKKANEN H. (2007), Leadership in Different Kinds of Regional Development Networks. Baltic Journal of Management 2(1), pp. 80-96.

Hardy C., Maguire S. (2008), Institutional Entrepreneurship. In: GreEnwood R. et al. (eds.), The SAGE Handbook of Organizational Institutionalism. SAGE, Los Angeles, pp. 198-217.

HenReKson M., SANANDajI T. (2010), The Interaction of Entrepreneurship and Institutions. Journal of Institutional Economics 7(1), pp. 47-75.

Horlings I., PADt F. (2013), Leadership for Sustainable Regional Development in Rural Areas: Bridging Personal and Institutional Aspects. Sustainable Development 21(6): pp. 413-424. 
Huggins R. (2000), The Success and Failure of Policy-implanted Inter-firm Network Initiatives: Motivations, Processes and Structure. Entrepreneurship \& Regional Development 12(2), pp. 111-135.

Kalantaridis C., Fletcher D. (2012), Entrepreneurship and Institutional Change: A Research Agenda. Entrepreneurship \& Regional Development 24(3-4), pp. 199-214.

LeICK B. (2017), Institutional Entrepreneurs and Small Firms: How Firm Practices are being Shaped in the Context of Demographic Transformations. Journal of Small Business and Entrepreneurship 29(1), pp. 1-24.

Leick B., Gretzinger S. (2018), Local Cases of Institutional Entrepreneurship: Change Agents in Regions Facing Demographic Change. In: Karlsson, C., Silander, D., Silander, C. (eds.), Governance and Political Entrepreneurship for Growth and Entrepreneurship in Times of Europe's Economic Crisis. Edward Elgar, Cheltenham, pp. 254-269.

Li D.D., Feng J., Jiang H. (2006), Institutional Entrepreneurs. The American Economic Review 96(2), pp. 358-362.

MaleCKi E.J. (1993), Entrepreneurship and Local and Regional Development. International Regional Science Review 16(1-2), pp. 119-153.

Mahzouni A. 82019), The Role of Institutional Entrepreneurship in Emerging Energy Communities: The Town of St. Peter in Germany. Renewable and Sustainable Energy Reviews 107, pp. 297-308.

Meng R. (2013), Entrepreneurial Innovation Capability of Rural Regions: An Underestimated Phenomenon? In: Tamasy C., Revilla Diez J. (eds.), Regional Resilience, Economy and Society: Globalising Rural Places. Routledge, London, pp. 173-194.

Mueller P. (2006), Entrepreneurship in the Region: Breeding Ground for Nascent Entre-preneurs? Small Business Economics 27(1), pp. 41-58.

Naldi L., Nilsson P., Westlund H., WiXe S. (2015), What is Smart Rural Development? Journal of Rural Studies 40, pp. 90-101.

North D.C. (1990), Institutions, Institutional Change and Economic Performance. Cambridge University Press, Cambridge.

Pacheco D.F., York J.G., Dean T.J., Sarasvathy S.D. (2010), The Coevolution of Institutional Entrepreneurship: A Tale of Two Theories. Journal of Management 36(4), pp. 974-1010.

Peredo A.M., McLean M. (2006), Social Entrepreneurship: A Critical Review of the Concept. Journal of World Business 41(1), pp. 56-65.

Perkmann M. (2002), Euroregions: Institutional Entrepreneurship in the European Union. In: Perkmann M.; Sum N. (eds.), Globalization, Regionalization, and Cross-Border Regions. Palgrave MacMillan, Basingstoke, pp. 103-124.

Perkmann M., Spicer A. (2007), 'Healing the Scars of History': Projects, Skills and Field Strategies in Institutional Entrepreneurship. Organization Science 28(7), pp. 1101-1122.

RAFIQui P. (2009), Evolving Economic Landscapes: Why New Institutional Economics Matters for Economic Geography. Journal of Economic Geography 9(3), pp. 329-353.

Schumpeter, J.A. (1934) (2008), The Theory of Economic Development: An Inquiry into Profits, Capital, Credit, Interest and the Business Cycle. Translated from the German by Redvers Opie. Transaction Publishers, New Brunswick (USA) and London (UK).

Shane S., Venkataraman S. (2000), The Promise of Entrepreneurship as a Field of Research. The Academy of Management Review 25(1), pp. 217-226. 
Sotarauta M. (2009), Power and Influence Tactics in the Promotion of Regional Development: An Empirical Analysis of the work of Finnish Regional Development Officers. Geoforum 40(5), pp. 895-905.

Sotarauta M. (2010), Regional Development and Regional Networks: The Role of Regional Development Officers in Finland. European and Regional Studies 17(4), pp. 387-400.

Sotarauta M., Pulkkinen R. (2011), Institutional Entrepreneurship for Knowledge Regions: In Search of a Fresh Set of Questions for Regional Innovation Studies. Environment and Planning C: Government and Policy 29(1), pp. 96-112.

TunBerg M. (2014), Approaching Rural Firm Growth: A Literature Review. Journal of Enterprising Communities: People and Places in the Global Economy 8(4), pp. 261-286.

Wennekers S., Thurik R. (1999), Linking Entrepreneurship and Economic Growth. Small Business Economics 13(1), pp. 27-56.

Willi Y., PÜTz M., MaYer H. (2018), Policy Entrepreneurship and Regional Development. CRED Working Paper No. 21. Centre for Regional Economic Development, University of Bern, Bern. 
